\title{
General Authority Investigators And Prosecutors Perma After Entry Number 2 Of 2012 Concerning The Adjustment Of Limitations For Crime And Number Of Fines In Light Of The Criminal Code
}

\author{
Dany Bramandoko ${ }^{1}$
}

Abstract. With the Perma No. 2 of 2012 then the misdemeanor case will be examined by a quick inspection event. The formulation of the problem and the purpose of this thesis is to describe and analyze the position of Supreme Court Regulation No. 2 of 2012 in the settlement of a misdemeanor, and to describe and analyze the implications of enforceability Perma No. 2 of 2012 against the authority of the investigators and prosecutors in cases of detention and the case investigation in court. This research method using normative legal research methods dengn type of research is descriptive analytical. Based on the analysis Perma No. 2 of 2012 to put forward the following results, that the legal position Perma No. 2 of 2012 is in substance related to the adjustment of the limits misdemeanor and fines in Perma No. 2 of 2012 which was ordered by higher laws or formed under the authority, in this case based on Article 79 of Act No. 5 of 2004 jo. Act No. 3 of 2009. The publication of Perma No. 2 of 2012 had an enormous impact on the implementation of the provisions of the detention authority possessed by the law enforcement agencies in the criminal justice process, especially in the judiciary under the authority of the Supreme Court. Of the offenses set out in the Supreme Court Regulation No. 2 of 2012 Section 1.

Keywords: Investigators And Prosecution Authority, Perma No. 2 of 2012

\section{Introduction}

The last few years have appeared anxiety of the society and law enforcement officials about the rise of a misdemeanor that perpetrators are punished as ordinary crime. For example, flip-flops theft and theft of a watermelon. Though the events background by necessity and not by accident. However, since applying Article 362 the Code of Penal, then the event was threatened with a maximum imprisonment of five years or a maximum fine of nine hundred rupiah.

The number of thefts judge actions by the small value of the item that is now being tried in court quite get the public eye. Society generally considers that it is not fair to judge actions were threatened with a penalty of five (5) years as stipulated in Article 362 of the Criminal Code therefore not comparable with the value of the stolen goods.

Case-theft case the light should fall into the category of minor criminal offenses (lichte misdrijven) which should more appropriately charged with Article 364 of the Criminal Code which pidanya threat than 3 (three) months imprisonment or a maximum of $\mathrm{Rp}$ 250.00 (two hundred and fifty twenty rupiah).

In line with the adjustment of the value of money stipulated in the articles of a misdemeanor, the Supreme Court found it necessary also to simultaneously tune the entire value of the rupiah which exist in the Criminal Code passed in 1960. Therefore, in 2012 the Supreme Court publishes Perma No. 2 of 2012 Restrictions on Adjustment of light crime and the amount of penalties in the Criminal Code. Perma It also stipulates that

\footnotetext{
${ }^{1}$ Student of Masters (S2) of Law Faculty of Law Unissula Semarang and Attorney in State Attorney Kendal Email danybramandoko@gmail.com
} 
if the accused previously imposed detention, President of the Court did not provide for the detention or extension of detention. This is because the case of minor criminal offenses should be prosecuted and terminated with a quick check shows that under Article 205-210 Book of Law Criminal Law (Criminal Code).

Procedural Law (Act No. 8 of 1981 on Criminal Code) has authorized the prosecution to the public prosecutor and in the case of a misdemeanor of the authority granted by law to the investigator. So in a nutshell for minor criminal case, the investigator after an investigation does not need to delegate to the prosecutor (as in the case with regular checks show) but directly delegate it to the court to be examined by a quick inspection event. Thus, a determination of whether a case will be examined by regular inspection event or occasion quick inspection, will be greatly influenced by the understanding of the investigator and the prosecutor, of course, will be whether an act was allegedly committed by a person (the suspect) includes admission to the qualifying clauses misdemeanor or not. Qualifying clauses would have to be re-referred to the articles of the laws that govern it, in this case the Criminal Code back to the substance of the law if so.

The application of the articles to be suspected by the investigator (and prosecution) will determine whether a case will be tried by the regular inspection of the event or the event a quick inspection. While this determination will also have an impact on the process that must be followed by the suspect during the investigation and prosecution, such as the much highlighted is the issue of detention, because if the article is suspected by the investigator (and prosecution) has been defined as a misdemeanor, then objectively have eliminated authorities for detaining suspects. References used by the investigator (and prosecution) of the Criminal Code. Then if the presence of perma issued by the Supreme Court is also legally binding to the investigator (and prosecution),

Based on the foregoing, the authors determine the formulation of the problem to be discussed in this paper are: How can the legal position Perma No. 2 of 2012 in the settlement of minor criminal ?; How implications for the enforceability of Perma No. 2 of 2012 on the Authority of the Investigator and Prosecution in Case of Detention And Examination Process Case in Court?

\section{Research methods}

The method used in this study is a normative legal research methods focusing on the inventory of positive law, principles and legal doctrine, legal discovery in the case in concreto, systematic law, the level of synchronization of law, comparative law and legal history. ${ }^{2}$ Peter M Marzuki in his book Legal Research, states that legal research is the process of finding the rule of law, principles of law, and the legal doctrines in order to address the legal issues at hand. ${ }^{3}$

While the type of research used in this study is a descriptive analysis, which is intended to give the data as accurately as possible about a situation or other symptoms. ${ }^{4}$ The term implies analytical grouping, connect, compare, and give meaning or definition of the actions chosen, descriptive data were collected for analysis as a basis to be able to solve problems that arise.

\footnotetext{
${ }^{2}$ Soerjono Soekanto dan H.Abdurrahman 2003 Metode Penelitian Hukum Rineka Cipta Jakarta p. 56.

${ }^{3}$ Peter Mahmud Marzuki 2005 Penelitian Hukum Kencana Prenada Media Group Jakarta p. 35.

${ }^{4}$ Bambang Sugono 2003 Metodologi Penelitian Hukum Raja Grafindo Persada Jakarta, p. 10
} 


\section{Results And Discussion}

\subsection{Legal Status Perma No. 2 of 2012 In the light crime Completion}

The Supreme Court is one of the institutions of judicial power as stipulated in the Constitution of the Republic of Indonesia. The Supreme Court is no longer the highest state institution as defined in the Conditions of the People's Consultative Assembly of the Republic of Indonesia No. III / MPR / 1978. The Supreme Court is the Supreme Court of the State of all courts, in carrying out their duties free from the influence of government and other influences.

Basically, the Supreme Court is not an agency or branch of state power by the power and authority to make legislation, because of the power and authority as a judicial power (judicial power) according to Article 24 paragraph (1) of the 1945 Constitution is the power to organize judicial administration to uphold the law and justice (to enforce the law and justice). ${ }^{5}$ However, the Supreme Court and the judicial bodies another can only be justified to the interpretation to seek and find meaning (to discover and to explore the meaning) or expand and mengelastikan sense (to extend or to enlarge and flexible the meaning), if provisions of the law -undangan concerned is not obvious meaning (unplain meaning), wrong formulation (ill-defined) or contain ambiguity (ambiguity). ${ }^{6}$

To know Perma position can be determined by analyzing the concept of a hierarchy of legislation in Indonesia. Hierarchies are leveling any kind of legislation based on the principle that legislation should not be lower odds with legislation higher. It is based on the elucidation of Article 7 (2) of Act No. 12 of 2011 Concerning the Establishment of Legislation.

Article 7 of Act No. 12 of 2011 set the type and hierarchy as follows:

- Types and hierarchy of legislation consists of:

- Constitution of the Republic of Indonesia of 1945;

- People's Consultative Assembly Decree;

- Law / Government Regulation in Lieu of Law;

- Government regulations;

- Presidential decree;

- Provincial Regulation; and

- Regulation of the Regency / City.

- The legal force of legislation in accordance with the hierarchy as referred to in paragraph (1).

Furthermore, in Article 8 paragraph (1) states that this type of legislation other than those referred to in Article 7 paragraph (1) include regulations set by the People's Consultative Assembly, House of Representatives, Regional Representatives Council, Supreme Court, Constitutional Court, Supreme Audit Agency financial, Judicial Commission, Bank Indonesia, the Minister, the Agency, agency, or commission equivalent established by Law or Government at the behest of the Act, the Board of Representatives Provincial Governor, House of Representatives District/City, Regent/the mayor, village head or the

\footnotetext{
${ }^{5}$ M.Yahya Harahap 2008 Kekuasaan Mahkamah Agung Pemeriksaan Kasasi dan Peninjauan Kembali Perkara Perdata Sinar Grafika Jakarta p.165.

${ }^{6}$ M. Yahya Harahap 1997 Beberapa Tinjauan Mengenai Sistem Peradilan dan Penyelesaian Sengketa Citra Aditya Bakti Bandung p.86.
} 
equivalent.Legislation referred to in paragraph (1) recognized and have binding legal force throughout ordered by legislation that is higher or established pursuant to the authority. As described in the background of the publication of this study Perma No. 2 of 2012 due to:

- That since 1960 the entire value of money contained in the Criminal Code has not been adjusted. This has implications for the use of ordinary theft clause under Article 362 of the Criminal Code on offenses under Article 364 of the Criminal Code;

- That when the value of money that exists in the Penal Code adapted to the current state of the handling of cases of minor criminal offenses such as theft light, darkening of light and the like can be dealt with proportionately given the penalty of the highest that can be handed down was three months in jail, and against the suspect or defendant can not be subjected to detention, and interrogation is used Fast Interrogation. Moreover judge actions can not be filed remedy of Cassation;

- That material changes to the Criminal Code is basically a matter of laws, but given the changes in the Criminal Code is expected to take quite a long while judge actions continue to go to trial, the Supreme Court deems it necessary to make adjustments to the value of the rupiah which exist in the Criminal Code is based on the gold price prevailing at 1960;

- That since 1960 the value of the rupiah has decreased by $\pm 10,000$ times if compared to the price of gold at this time. For those reasons, the entire amount of rupiah that exist in the Criminal Code unless Article 303 and 303 buses need to be adjusted;

- Rules that the Supreme Court did not intend to change the Criminal Code, the Court simply adjusting the value of the money that has been very inconsistent with current conditions. It is intended facilitate law enforcement particularly judges, to give justice to the cases before it.

Based on these things then ditetapkanlah Perma No. 2 of 2012. Thus, in addressing the criminal case that was charged with the articles of the Criminal Code that may be imposed by the criminal, the judge shall observe this Perma.

Basically, with this Perma not just referring to the value of money in a criminal action. This certainly must be understood by all parties, because the application of Perma this is not shown in all of the offenses contained in the Criminal Code, but merely applied to the category of a mere misdemeanor.

\subsection{Implication Perma Entry No. 2 of 2012 against the Authority investigators and prosecutors in Case of Detention And Examination Process Case in Court}

The publication of Perma No. 2 of 2012 had an enormous impact on the implementation of the provisions of the detention authority possessed by the law enforcement agencies in the criminal justice process, especially in the judiciary under the authority of the Supreme Court. Of the offenses set forth in Perma No. 2 of 2012 Article 1, the examination process using the Fast Interrogation under Article 205-210 Criminal Procedure Code. In the provisions of the Criminal Procedure Code stipulates that of the cases were severed with the Fast Interrogation is not done to perpetrators of criminal detention.

Police as investigators in the process of investigating cases of theft are usually more focused on the provision of Article 362 of the Criminal Code. Police could weigh whether the case could be continued in the investigation process or not. In this context, the police 
will do the construction formulation of the provisions of Article 362 of the Criminal Code. This is because of limitations mild theft under Article 364 of the Criminal Code is currently the goods or money whose value under $\$ 250$, - (two hundred fifty rupiah). The value certainly is not appropriate at this time, had almost no items for under $\$ 250$, - (two hundred fifty rupiah).

With the Perma No. 2 of 2012, Article 364 of the Criminal Code back effectively and deliver justice to thieves stealing the value of goods or money that is worth no more than Rp 2.500.000,00 (two million five hundred thousand rupiah).

Perma implementation mechanism No. 2 of 2012, namely after the judge actions misdemeanor until the examination before the court, in accepting the transfer of the case from the public prosecutor, the chairman of the court shall take into account the value of the goods or the money becomes the object of the case. If the value of the goods or the money is worth no more than Rp 2.500.000,00 (two million five hundred thousand rupiah) as determined predetermined Perma No. 2 of 2012, the case was terminated by the Crime Investigation Light, as stipulated Article 205-210 Criminal Procedure Code. President of the Court set a single judge to hear the case.

The absence of binding properties of Perma No. 2 of 2012 to investigators and prosecutors, it means that the Perma enters into force after the judge actions entered in the criminal courts, namely by:

- Courts in receiving the delegation of cases of theft, embezzlement, fraud, fencing of the Prosecutor General, the Chairman of the court shall take into account the value of the goods or the money becomes the object of the case.

- If the value of the goods or the money is worth no more than Rp 2.500.000,00 (two million five hundred thousand rupiah), the President of the Court immediately set a single judge to examine, hear and decide the case in the event Quick checks under Article 205- 210 Criminal Procedure Code.

Article 3 Perma No. 2 of 2012 mengatura that each fined the maximum amount under the Penal Code threatened doubled to 1,000 (one thousand) times. In these conditions there is an exception that is against Article 303 paragraph (1) and (2), Article 303 bis paragraph (1) and (2) of the Criminal Code. The exception due penalty of two articles has been amended in 1974, through Act No. 7 of 1974 on Gambling Control.

Furthermore, Article 4 specifies that in dealing with criminal assault were charged with the articles of the Criminal Code that may be imposed penalty, the judge should pay attention to the adjustment of the value of fines in accordance with the provisions of Perma No. 2 of 2012. This means that as far as possible the judges to consider sanctions fines as the choice of punishment to be imposed, taking into account the severity of the act and sense of justice.

There is no authority directly Supreme Court against the investigator and the prosecutor so that the issuance Perma has no binding properties to investigators and prosecutors. However, with the appeal of the Supreme Court to all the courts in order to disseminate appropriate adjustments to the content Perma to the AGO, the close relationship between the function and authority of law enforcement officials (investigators, prosecutors, courts) as described above can be used as the basis of the application of the perma No. 2 of 2012 by investigators and prosecutors.

\section{Closing}




\subsection{Conclution}

- The legal status of the Supreme Court Regulation No. 2 of 2012 as the substance is concerned the adjustment limitation misdemeanor and fines in the Supreme Court Regulation No. 2 of 2012 ordered by the higher laws or formed under the authority, in this case, based on Article 79 Law Number 14 of 1985 About the Supreme Court, as amended by Act No. 5 of 2004 jo. Act No. 3 of 2009 which reads: "The Supreme Court can set up more things that are necessary for the smooth administration of justice, if there are things that have not been sufficiently regulated in this Law. The legal basis rooted in Article 24 paragraph (1) of the Constitution of the Republic of Indonesia Year 1945 mandates that:

- The publication of Perma No. 2 of 2012 had an enormous impact on the implementation of the provisions of the detention authority possessed by the law enforcement agencies in the criminal justice process, especially in the judiciary under the authority of the Supreme Court. Of the offenses set forth in Perma No. 2 of 2012 Article 1, the examination process using the Fast Interrogation under Article 205-210 Criminal Procedure Code. In the provisions of the Criminal Procedure Code stipulates that of the cases were severed with the Fast Interrogation is not done to perpetrators of criminal detention.

\subsection{Suggestion}

- For the government should appreciate the Supreme Court Regulation No. 2 of 2012 by making the law in order to reach all those who are in the legal system of criminal justice as an investigator mauapun public prosecutor can run and consistently change the articles of the Criminal Procedure Code can not keep up with the times to be effective back and can be used by law enforcement officials (Police).

- For investigators and prosecutors for more attention to the Supreme Court Regulation No. 2 of 2012 in dealing judge actions misdemeanor.

\section{BIBLIOGRAPHY}

[1] Bambang Sugono 2003 Metodologi Penelitian Hukum Raja Grafindo Persada Jakarta.

[2] M. Yahya Harahap 1997 Beberapa Tinjauan Mengenai Sistem Peradilan dan Penyelesaian Sengketa Citra Aditya Bakti Bandung.

[3] -------- 2008 Kekuasaan Mahkamah Agung Pemeriksaan Kasasi dan Peninjauan Kembali Perkara Perdata Sinar Grafika Jakarta.

[4] Peter Mahmud Marzuki 2005 Penelitian Hukum Kencana Prenada Media Group Jakarta.

[5] Suryono Soekanto dan H.Abdurrahman 2003 Metode Penelitian Hukum Rineka Cipta Jakarta.

[6] The Book of the Law of Criminal Law

[7] Act No. 15 of 1961 About the Principal Provisions Prosecutor.

[8] Act Number 48 of 2009 concerning Judicial Authority.

[9] Act No. 12 of 2011 Concerning the Establishment of Legislation.

[10] Supreme Court Regulation No. 2 of 2012 on Limitation Adjustment light crime and the amount of penalties in the Criminal Code. 